第23回紙パノフ計装技術発表会・特別講演 2

\title{
月探查計画について
}

宇宙開発事業団 技術研究本部月利用推進研究室 横 山 隆 明

\section{Exploration Program for the Moon}

Takaaki Yokoyama

National Space Development Agency of Japan

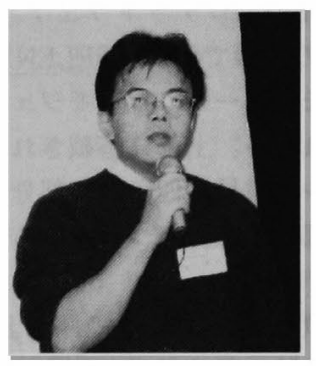

The most exciting on the relationship between humankind and the Moon was probably the Apollo program undertaken during 1969-1972. The Apollo program brought us numerous scientific data. but unfortunately the program did not give sufficient data to resolve fundamental question on the Moon. After 30 years from the Apollo program, SELENE (SELenological and ENgineering Explorer), developed in the first ISAS/NASDA joint Lunar program, is getting ready for lunch by H-IIA rocket in 2004. The major objectives of the mission are to obtain the lunar origin and evolution, and to develop the technology for the future lunar exploration.

分類： $Y_{1}$ 基整科学一般, $V_{1}$ 計装・制御システム一般

\section{1.はじめに}

月と地球の関係は抢そらく人類が生まれてから現代 に至るまで，常に人々の興味を引いてきた問題であろ う。月の満ち久けは, 古代人の時の基本になっていた ばかりでなく，生物活動のリズムの源泉ともなってい る。月がどのようにして誕生し現在に至ったかを明ら かにすることは，月自身に対する科学的成果のみなら す，地球に対する理解を梁めてくれるデータが得られ るものと考えられる。

さらに月の探查は科学的成果を上げられるというだ けでなく, 将来の人類の共存, 発展にとっても大きな 意義を持っている。月は地球に最も近い天体として, 人類が宇宙に活動領域を広げるための最初のステップ となるとも思われるからである。月の表面にある $\mathrm{Al}$,
$\mathrm{Mg}, \mathrm{Si}, \mathrm{O}$ や $\mathrm{He}$ などの元素を月の資源として利用 することや，月の環境を利用した月面上での様々な観 測が将来人類に恩恵をもたらすことも期待されている からである。

アポロの着陸から 30 年経った現在,「月の起源と進 化」「将来の月の利用の可能性の調查」を主な目的と し, 2004 年, H-IIA ロケットを用いた打ち上げを目 指して日本ではじめての大型の月周回衛星計画：セレ ーネ (以下 SELENE : SELenological and Engineering Explorer) 計画が宇宙科学研究所 (ISAS : Institute of Space and Astronautical Science) と宇宙開発事業団 (NASDA : National Space Agency of Japan) の共同 ミッションとして進められている。 


\begin{tabular}{lll} 
横 山 隆 山 明 \\
\hline
\end{tabular}

\section{SELENE 計画の概要}

SELENE は「月の起源と進化」「将来の月の利用 の可能性」を解明することを目的に，2004 年，H-IIA ロケットを用いて打ち上げられる予定である。H-IIA ロケットは, 21 世紀における人工衛星の打上げ・宇 宙ステーションへの補給等の多様な輸送需要に, 高い 信頼性を確保しつつ低コストで対応するという要請に 応えるために, H-IIロケットの開発技術成果をもと に開発されるロケットであり, 静止軌道に 4 トンの衛 星を打ち上げる能力を持っている。

図 1 はH-IIA ロケットフェアリングに納められた SELENEの外観である。SELENEはリレー衛星，ミ ッションモジュール, 推進モジュールの3つの部分か ら構成されいる。上部に搭載されている 8 角形形状の 部分がリレー衛星, 四角形の部分がミッションモジュ ール, 下部の着陸脚がついている部分が推進モジュー ルである。

H-IIA ロケットによって打ち上げられた SELENE は, 約 5 日後に月の軌道傾斜角 95 度の楕円周回軌道 に投入される。ここでリレー衛星が分離され遠月点高 度 $2,400 \mathrm{~km}$, 近月点高度 $110 \mathrm{~km}$, 軌道傾斜角 95 度 の楕円軌道を周回する。リレー衛星を分離したSELENE はその後数段階に分けて楕円軌道から徐々に軌

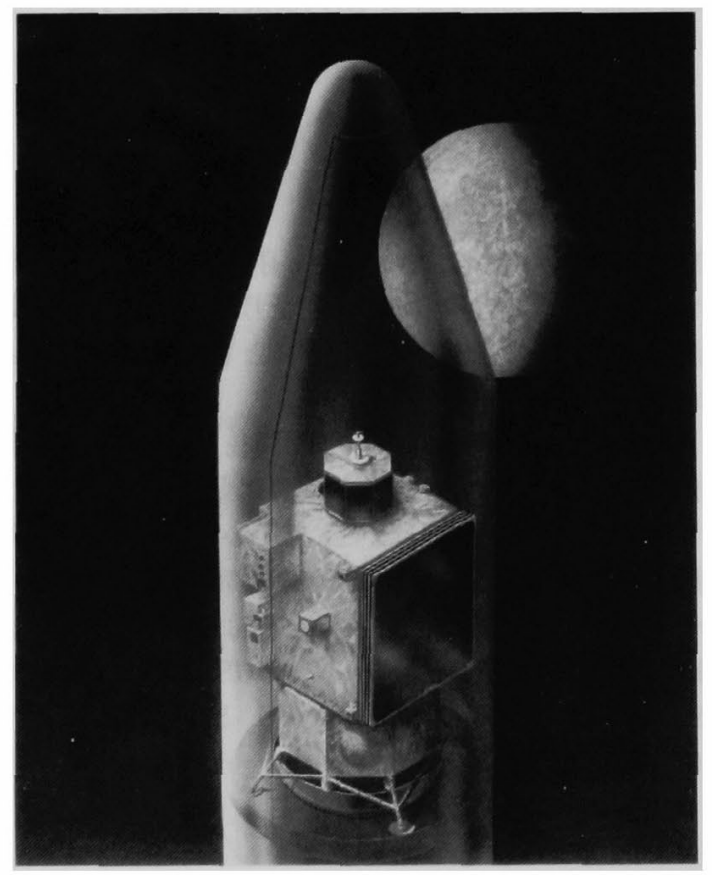

図１フェアリング收納時の SELENE（表紙参照）
道を変更し，打ち上げから約 15 日後に高度 $100 \mathrm{~km}$ の円軌道 (周回観測軌道) 一達し月の周回衛星となる。 周回観測軌道に達した後, 磁場計測装置用伸展マス ト，レーダーサウンダー用アンテナを伸ばし，各種の 観測体制を整える。ミッションモジュールにはその他 の各種観測機器が搭載されている。観測機器の多くは 月面を観测する機器であるため, ミッションモジュー ルの月面指向面に集中的に設置されている。ミッショ ンモジュールは月周回軌道上で, 約 1 年間, 月の全球 にわたって月面の地形, 鉱物分布, 元素分布, 月磁場 や月重力場などの各種の観測を行う。約 1 年間の観測 運用が終了すると，推進モジュールが分離され，月面 への軟着陸実験を行う予定である（図2）。

\section{SELENE のコンフィギュレーション}

SELENE はリレー衛星, ミッションモジュール， 推進モジュールから構成されている。

・リレー衛星

リレー衛星は姿勢制御装置を持たないスピン安定型 で約 $40 \mathrm{~kg}$ の小さな盛星であるが，いくつかの役割を 担っている。まず周回衛星が月の裹側へ入ってしまう 時に地上観測所との信号が途絶えてしまうのを回避す るため周回衛星と地上観測所の間の信号を中継を行う。 この時リレー衛星はスピン安定によって軌道を維持し ているため, リレー衛星の軌道をモニターすることで 月の重力場計測を行うことができる。またリレー衛星 にはVLBI（超長基線電波干涉計）用の電波源も搭載 されており，推進モジュールの着陸後に推進モジュー ルに搭載されている月面の VLBI 用電波源と組み合わ せることによって（相対 VLBI），さらに精密な月の 重力場計測をおこなう（図 3)。

・ミッションモジュール

ミッションモジュールは $2 \mathrm{~m} \times 2 \mathrm{~m} \times 4 \mathrm{~m}$ の大きさ があり重量は約 1.5 トンある。ミッションモジュール には，太陽電池パドル，各種観測機器が搭載されてお ク, SELENEにおける科学钼測を担う部分である。 SELENEに搭載されている観測機器の一覧を表 $1 に$ 示す。ミッションモジュール前方には約 $15 \mathrm{~m}$ の長さ で磁場計測用のマストが伸び，四方には約 $15 \mathrm{~m}$ の長 さでレーダサウンダー用のアンテナがのびている。ミ ッションモジュールは月の周回軌道上で約 1 年間の観 测を行う予定である。

・推進モジュール

推進モジュールは打ち上げ後の姿勢制御及び月面へ の軟着陸実験を行う部分である。8 角形状をしており， 外形では約 $2 \mathrm{~m} \times 2 \mathrm{~m}$, 着陸脚を含めた高さは約 1.8 


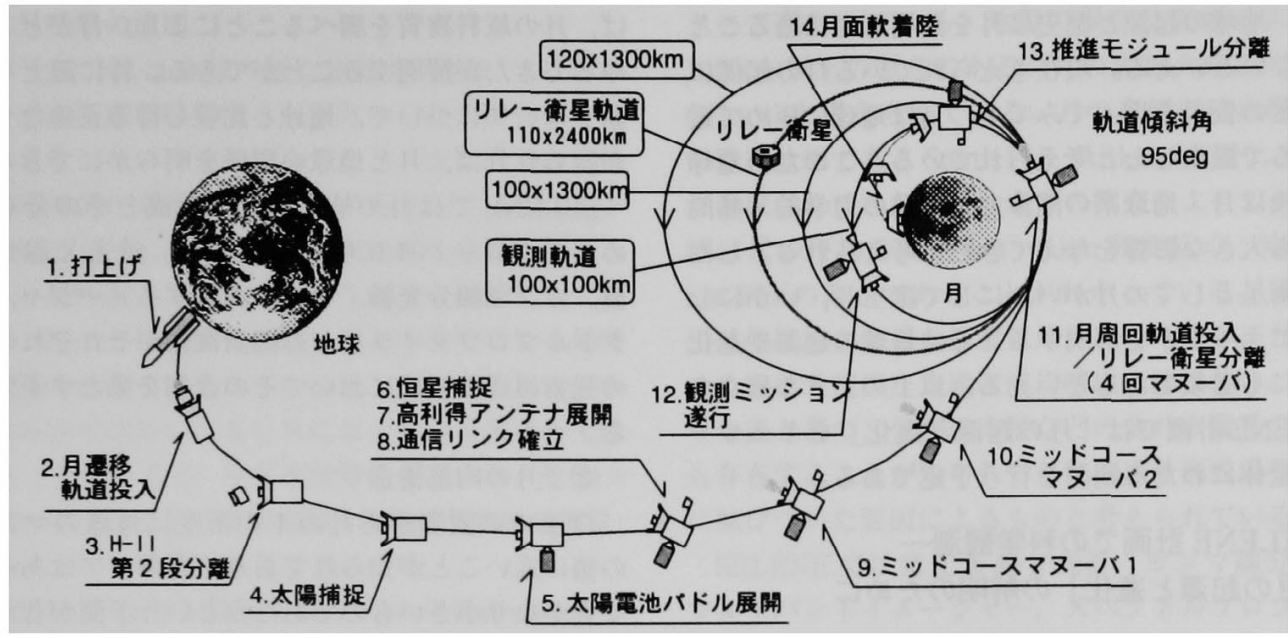

図 2 SELENEミッションプロファイル

表 1 SELENE 観测機器一覧

\begin{tabular}{l|l}
\hline 蛍光 $\mathrm{X}$ 線分光計 & ガンマ線分光計 \\
\hline スペクトルプロファイラ & 地形カメラ \\
\hline レーザ高度計 & 衛星電波源・月面電波源 \\
\hline 月磁場観測装置 & プラズマイメージャ \\
\hline プラズマ観測器 & 月電波科学観測 \\
\hline マルチパンドイメージャ & 月レーダサウンダ \\
\hline リレー衛星搭載中継器 & 粒子線計測器 \\
\hline
\end{tabular}

mである。推進モジュールはミッションモジュール とともに約 1 年間月を周回した後にミッションモジュ ールと分離され, 月面への軟着陸実験を行う。月面へ の軟着陸を終えた推進モジュールは，内部に搭載され た電波源を用いてリレー衛星と共にVLBIによる月重 力場観測を行う。電波源は約 2 ヶ月問稼働し月面での 長期滞在技術の実証も行う。

\section{4. 月探査の意義}

1957 年 10 月 4 日, 旧ソ連により人類最初の衛星ス プートニク 1 号が打ち上げられ，その後の米ソの宇宙 開発競争のターゲットとして月探査計画は進行してい く。そして 1969 年 8 月 20 日のアポロ 11 号の月面着 陸が成功し，同時に宇宙開発競争も第一幕を終了した。 アポロ計画では計 12 人の宇宙飛行士が月面に降り立 ち, 約 $380 \mathrm{~kg}$ の月の石や砂が持ち帰られ，また各種 の観測機器を月面に設置した。現在でもその特持ち帰

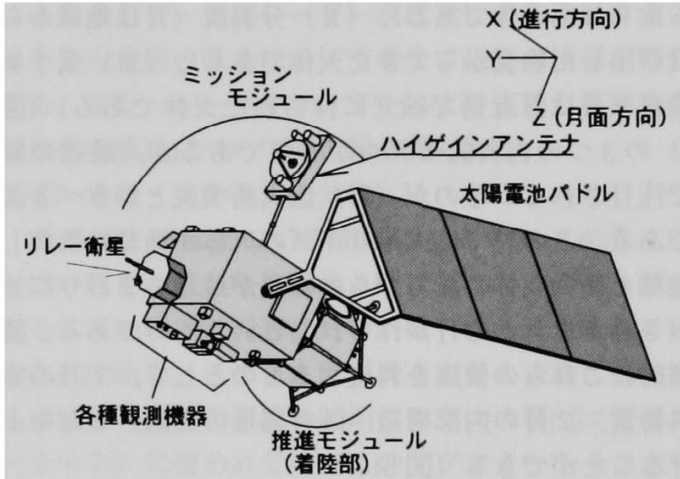

図 3 SELENEコンフギュレーション

られた月の物質の分析や，設置された観測機器を用い た観測が続けられている。

このように月は今でも人類が地球外に足跡を残して いる唯一の場所であり，確かにアポロ計画によって人 類の月に対する考え方を大きく変わったが，科学的見 地からするとこれまでの月探査は甚だ不完全であった といわざるを得ない。人が降り立った地点は 6 筒所に 過ぎず，月の石や砂が採取されたのも限られた地域で ある。また軌道上からの観測についても例えば可視光 域では赤道 \pm 20 度以内の地域の約 $50 \%$ が 2-30 m の 分解能で調べられたに過ぎず，その他の波長域や磁場 計測についても限られた地域の観測にとどまっている。 むしろこれらの結果から，今後月についてなにを調べ れば良いかを教えてくれたともいえる。

また月は地球に最も近い天体であり, 地球誕生の頃 から月と地球は変化を共有し現在に至ったと考えられ 
ている。地球の起源と歴史は月を無視しては語ること ができないといえる。現在考えられている月の起源に 関するどの仮説を採ってみても, 月は地球に極めて近 いところで誔生したと考えられている。このため地球 誕生直後は月 - 地球系の潮汐力が地球の力学的 - 熱的 進化にも大きな影響を与えてきたと考えられる。した がって衛星としての月がいかにして誕生し、いかにし て現在に至ったかを解明することは地球の起源や進化 の解明にも必須であるといえる。以上のような観点か ら SELENE 計画では「月の起源と進化」をキーワー ドに月全体にわたる観測を行う予定である。

\section{SELENE 計画での科学観測一 \\ 「月の起源と進化」の解明のために}

\section{1 月の起源を解明するために}

現在月の起源に関しては, いくつかのモデルが提案 されている。その中でも（I）捕獲説（月は地球にと らえられた天体である)，（II）分裂説（月は地球から 飛び出した物質からできた天体である)，（林）双子集 積説（月は月近傍で独立に作られた天体である）（図 4）の 3 つの古典的モデルが有名であるが, 最近の説 で注目されているのが（N）巨大衝突説というべき説 である。この説では火星サイズの天体が地球に衝突し 地球と衝突天体の双方からの物質が地球のまわりに放 出され，それから月が作られたというものである。観 測的にこれらの仮説を判定するものとして，(1)月の原 料物質, (2)月の内部構造, (3)月磁場の成因, などを上 げることができる（図5)。

\section{(1) 月の原料物質}

太陽系の形成された時を考えると，太陽からの距離 によって圧力や温度条件が異なるため，それぞれの惑 星の原料物質の化学組成には差異が生じていたと思わ れる。例えば巨大衝突説によって月が誕生したとすれ
ば，月の原料物質を調べることにより，月がどこから やってきたか解明することができる。特に鍵となる元 素クルーブについて, 地球と比較し得る正確なデータ が得られれば，月と地球の関係を明らかにできる。

SELENEでは月の地殸の元素組成とその分布を初 めててグローバルに明らかにする。蛍光 X 線分析装 置, ガンマ線分光器, マルチバンドイメージャ, スペ クトルブロファイラなどの観測機器がそれぞれの得意 の元素組成の領域においてその役割を果たす予定であ る。

\section{（2）月の内部構造}

今までの観測から月の平均密度は地球のマントル の值に近いことが知られており，そのコアはあるとし てもかなり小さいものであろうという予測が昔からな されてきた。月が隕石の集積によって作られてたとす れば，月岩石中の金属元素の存在度を説明するために は月のコアの半径は $360 \mathrm{~km}$ 以上必要で, 月が地球の マントルと同じ物質で作られたとすると，コアの半径 は $285 \mathrm{~km}$ より小さくなければならない。つまり月の コアの半径の大きさがわかれば，今までに分析されて いる月岩石中の金属元素の存在率を考えることにより， 月の原料物質が始原的隕石であるか地球のマントルで あるかが判断できる。

SELENE ではリレー衛星を使った月の裹側の重力 探査, リレー衛星と着陸機に搭載された電波源を使っ た VLBI 観測によって月の精密な重力場を測定する。 これにより月のコアの大きさについてさらに詳しい情 報が得られる。さらに月面上にはマントルの岩石が露 出していると思われる地域があり，これらの地域の鉱 物組成, 化学組成がわかれば月の内部に関する物質科 学的データとなる。これにはおそらく地形カメラ、マ ルチバンドイメージャ, スペクトルプロファイラが有 効であろう。

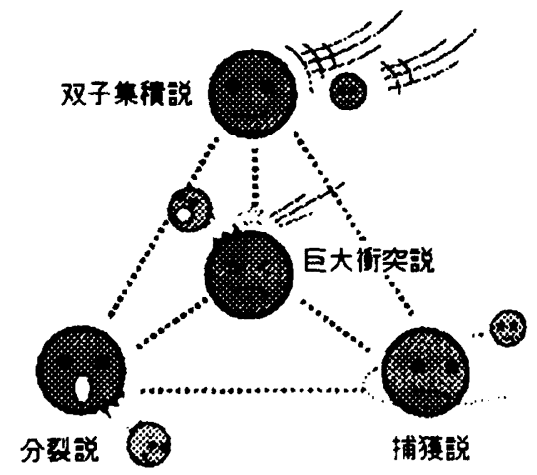

図 4 月の起源

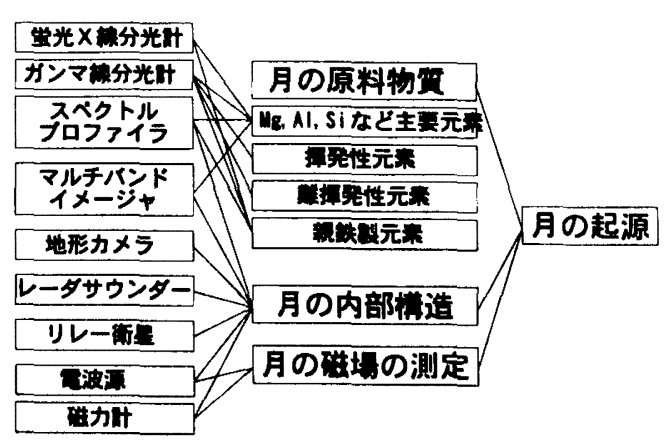

図 5 月の起源の解明のための観測 


\section{（3）月磁場の成因}

現在では月には地球の様な磁場が存在していない が，アポロ計画で持ち㷌られた月の岩石には大きな残 留磁化をもっていたものがあること，また月表面には 磁気異常地域が存在することが観測されていることか ら，かつての月には地球の样に大規模な磁場が存在し ていた可能性がある。このような磁場の起源としては 月のコアによるタイナモ作用，隕石の衝突による局所 的な磁場などが考えられているが，どれが正しいのか 未だ明らかではない。もし月にコアによるタイナモ作 用があったとすると，月形成初期にマントル・流体コ ア構造があったことになり初期月深部の具体的な物質・ 熱構造について解明されることになる。

SELENEでは月の磁場をほほ月の全表面にわたっ て行い, その結果と地形カメラ, マルチバンドイメー ジャによる物質探査, レーダサウンダーによる地下構 造探查の結果とも併せて, 磁気異常は地域はどのよう な地下椿造なのか, 何が磁気異常の原因なのか解明す ることが期待されている。

\section{2 月の進化を解明するために}

月の誔生から現在の形に至ったプロセスを月の進化 と呼ぶ。月は地球と同じ固体惑星に分類され, 極めて 地球近傍で進化していったため, 月の進化過程を明ら かにすることは月の科学だけでなく地球の誕生直後か らの進化過程にも新たな知識を与えてくれる。月の進 化は(1)月の表㑡と裏㑡の地款の厚さの違い（月の二分 性)，(2)地殻・マントルの分化・進化，(3)マントル対 流など表層のテクトニクス（変形の様式や地質学的構 造）を解明することによって明らかにすることができ る(図6)。

（1）月の二分性

月は表と裹で大きく様相が異なっている。表㑡は 海と呼ばれている黒に近い色をした玄武岩溶岩が吹き 出した比較的平坦な領域が多く, 裹側の多くはクレー

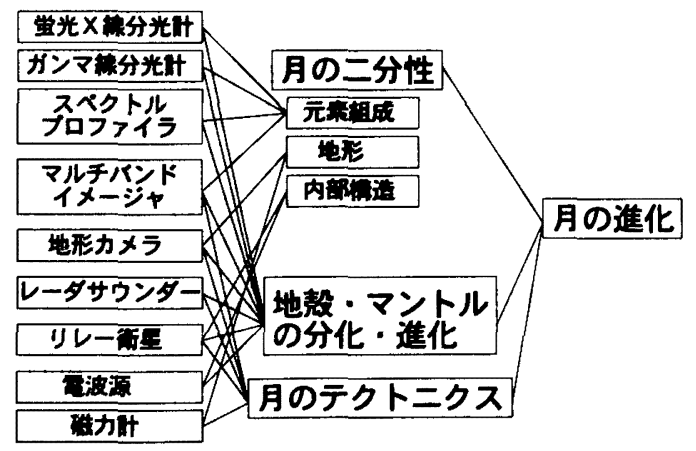

図 6 月の進化の解明のための観測
ターで覆われている。地款の厚さは亭面の方が厚く $100 \mathrm{~km}$ 以上の厚さである（月の表側の地款の厚さは $60 \mathrm{~km})$ と考えられている。月の襄側には太陽系最大 の衝突盆地である South Pole-Aitken (直径 2, $250 \mathrm{~km}$ ) が形成されており，これまでの探査によって，この地 域は月の平均高度から $4 \sim 8 \mathrm{~km}$ 程度低く, 地凯は 40 $\mathrm{km}$ 以下の薄さであることがわかっている。月の裹側 には他にも大規模な衝突盆地が存在するが, 月の表面 のように大規模な玄武岩溶岩噴出の跡は無い。このよ うな表と裏の二分性は火星などの他の太陽系の天体に も存在することが知られており, 惑星形成過程と密接 に結びついた要因によるものと考えられている。

SELENE では蛍光 X 線分光計, ガンマ線分光計, マルチバンドイメージャー，スペクトルプロファイラ などの各機器による月全体にわたる元素組成のマッピ ングを行うことによって，表面の鉱物組成，元素組成 の違いを明らかにし，さらにリレー衛星，月面電波源 による重力データ, レーザー高度計による地形計測デ 一タから地款の厚さについて今まで以上の情報が得ら れる。また,レーザサウンダーにより表側と裹側の上 部地殻の構造についての情報も得られる。

(2) 地款・マントルの分化

月の海と呼ばれている領域はクレーターが多く白 っぼい色をしており, 高地と呼ばれている。白っぼい 色をしているのは岩石に白い斜長石が多く含まれてい るためである。このように斜長石が多く表面に存在す るのは, 月はその形成の初期にマグマの層（マグマオ ーシャン）に覆われていてこのマグマオーシャンから 軽い斜長石が表面に浮かび上がり，初期の地款を形成 し，固化したカンラン石やキ石は重いので，マグマオ ーシャンの底に沈み月のマントルを形成したと考えら れる。前述したように月の表と裹では地款の厚さが異 なっており，この違いは月の進化の極めて初期段階に 生じたと思われている。マクマオーシャン説が正しい とすれは，マグマオーシャンから地款・マントルが分 化して地款が形成されていく極めて初期段階において 既に大規模な二分性も生まれていたことになる。

月の地款・マントルの初期分化過程の問題は, SELENEによる表層の元素・化学組成の詳しい二次元的 マッピンクや重力探查, レーダサウンターーによるレコ リスに覆われた木内地款の地下構造の解明を通じて明 らかにされるものと考えられる。

(3) 月のテクトニクス

月の進化過程においての内部変化は表層のテクト ニクスに反映されていると考えられる。これは地球で 考えても当てはまることであるが，地球の表層はその 
誕生以来今日まで変化し続けている。月の場合はサイ ズが小さいため激しい内部構造の変化期間は極めて短 く，月の歴史の初期のマントルの状態を反映したテク トニクスが保存されている。

例えば深部からもたらされ表面に広がる火山岩の鉱 物・化学組成はその時のマグマの温度に依存するので 月の過去の温度構造を知る手がかりとなり，揮発物質 が多い噴火の場合などは特有の地形を残すので，揮発 物質の推定の手がかりとなる。

SELENEではマルチバンドイメージャとスペクト ルプロファイラによる組成マッピングと，地形カメラ による画像データを組み合わせることにより，月のテ クトニクス, 過去の温度構造に対する理解が樑まると 期待されている。

\section{SELENE 計画での技術開発一}

「将来の月の利用の可能性」の調査のために

\section{1 月の環境}

月には大気がなく太陽光が直接降り注いでおり，月 面の温度は赤道域で昼間約 120 度, 夜間は約 -170 度 まで変化している。また太陽風や銀河放射線などが直 接降り注ぎ，非常に過酷な環境である。しかし月面を 覆っているレゴリス（Regolth）と呼ばれている細か い砂は鉄, アルミ, シリカ, カルシウムなどが酸化物 で形成されており，レゴリスの利用は宇宙資源として 有望視され, 月は人類が宇宙に進出する第一歩となる 可能性も秘めている。

このような将来の月利用の時代のためには，まだ多 くの技術的開発を行わなければならないが, SELENE 計画ではその第一歩として, 月面への軟着陸実験及び 約 15 日間続く月の夜間の滞在技術の習得を目的に実 験を行う予定である。

\section{2 推進モジュールの月面軟着陸穾験について}

月面軟着陸は 1960 年代に既に米国及び旧ソ連によ って達成されているが, 月面への軟着陸を実施するた めには以下の課題が存在する（図 7)。

\section{(1) 航法誘導制卸技術}

月周回軌道上から動力降下して, 着陸機自らが軌 道決定誤差, 航法誤差, 月面標高差などの誤差を吸収 しながら，目標とする地域において高度 $0 \mathrm{~m}$ で速度 0 $\mathrm{m}$, 姿勢垂直を達成し，月面軟着陸を果たす必要があ る。

このためには航法センサーとして慣性誘導装置と電 波高度計/速度計を搭載しエンジンの燃料消費を可能 な限り最小とするような制御を行うことが重要である。 垂直降下については降下開始高度をできるだけ低くす

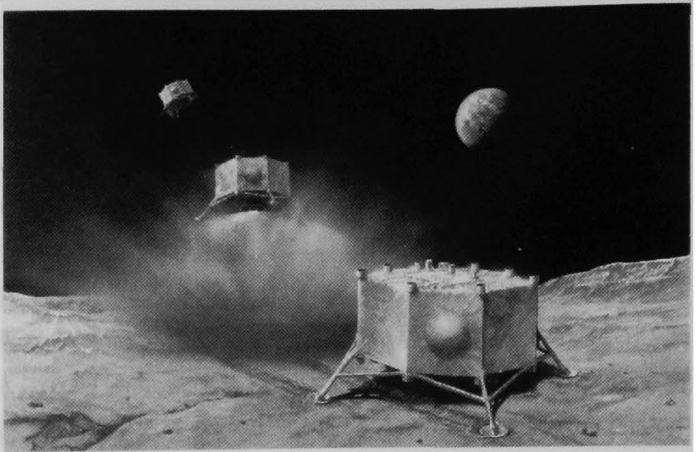

図 7 軟着陸を行う推進モジュール

ると共に自由落下と最大減速を組み合わせた飛行プロ ファイルを設定する必要がある。

(2) 推力制御技術

動力降下による軟着陸にはロケットエンジンの推 力制御が必須である。アポロなどの過去の月面着陸気 は推力を連続的に可変とするスロットリングエンジン を搭載していた。SELENE計画ではエンジンの複雑 化を回避するため, エンジンの ON/OFF 作動により 対応する。

\section{(3) 衝撃吸収技術}

安全で着実な月面への着陸のためには，月面着陸 時の転倒を避け，搭載機器へ衝撃を及ほさないような 着陸のための装置を開発する必要がある。SELENE 計画ではアポロ計画と同様のクラッシャブルダンパー 内蔵の着陸脚を開発中である。この脚は垂直の速度だ けでなく水平の速度成分も吸収しなければならず，さ らにある程度の傾斜地（最大 20 度を想定）にも着陸 できる能力が必要である。

\section{(4) 月面滞在技術}

月面軟着陸実験での最大の目的は安全な着陸を行 うことであり，月面着陸後はその機能は停止する。た だし着陸機には唯一のペイロードである月面電波源が 搭載されており，着陸後約 2 ヶ月間にわたりリレー衛 星と共に相対 VLBIにより月重力場の精密な測定を行 う。そのためには約 15 日毎に繰り返される昼夜の温 度差を克服することが必要で，SELENE 計画ではぺ イロード機器を納めた容器を断熱ブランケットで覆い, さらに熱伝導ロスを最小限にするよう,この容器を GFRP ベルトで宙づりにし，外部との熱授受を遮断し た状態でヒータによる温度制御を行う予定である。

\section{7. 終わりに}

2004 年に打ち上げられる SELENE 計画は日本で始 めての月探查計画である。SELENE 計画では「月の 
起源と進化」「将来の月の利用の可能性」の調査を目 的に，今までになく月全体を総合的な探查を行う予定 である。SELENEによる探査によって今まで残され てきた月の謎について多くの知見が得られ, 将来的な 月の利用のための技術が習得されることが期待されて いる。

月には $\mathrm{Al}, \mathrm{Mg}, \mathrm{Si}, \mathrm{O}$ や $\mathrm{He}$ などの資源があり， 宇宙開発の第一歩として利用することが期待されてい る。また大気が無く地震（月震）も少ないという月の 環境を利用した天体観測など, 月面上での様々な観測
が将来人類に恩恵をもたらすことも期待されている。 このような将来的な宇宙開発において月開発が果たす 役割は大きい。SELENE 計画はその第一歩として位 置づけられると考えられる。月開発を単なる夢物語で はなく現実のものとするために, SELENE 計画を着 実に進めて行くことが必要であると認識している。

*表紙の写真は, 月周回中の SELENE：宇宙開発事業 団つくば宇宙センター提供。 


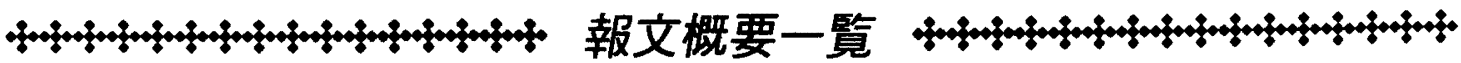

\section{これからの製造業システムとマイクロソフトの取り組み}

マイクロソフト株式会社 インダストリーソリューション部 佐野 勝大

近年, IT の進化は目を見張るものがあり，もはや企業の業務の根幹となりつつあり，製造業におい てもその例外ではない。

従来，日本の製造業では，優秀な従業員の経験と技術，勘に支えられ，飛躍的な発展を遂げてきたが， 少品種大量生産の時代が䅂駡を迎え，慢性的な景気の低迷に加えて消费者のニーズが多様化してきた今， マーケットに即した製品, サービスをいかにリアルタイムに送り出せるかがキーになってきたといえる。 そのためには, 今後の製造業は永遠の命題である生産効率, 品質の向上, コスト削隇というテーマを, 従来の人，もの中心から IT 技術を有効に活用した業務の改勒急枒であり，今後グローバル化の中で 主流となるサブライチェインを含めたヴーチャル生産体制を完成させることが生き残りの拜といえる。 当論文では，このような環境の中，IT技術がどのように製造菜にとって適用されるへきかを，マイ クロソフトが展開する Windows DNA for Manufacturing を中心に解説する。

(本文 15 ページ)

\section{月探査計画について}

\section{宇宙開発事業団 技術研究本部月利用推進研究室 横山 隆明}

月と人類との関連において, 最も画期的な出来事は 1969 年から 1972 年まで行われたアポロ計画であ ろう。アポロ計画は月について多くの科学的データを我々にもたらしてくれたが，月の本当の謎を解明 するまでには至らないで終了している。

アポロ計画から 30 年経った現在, アポロの成果の分析も進み, 月を理解することが, 地球や, 他の 惑星の謎を解くために重要な意義を持つことが再認識されている。このような状況の中，日本で初めて の大型の月探査機が 2004 年頃に打ち上げを目指し計画されている。この計画はセレーネ (SELENE : SELenological and Engineering Explorer) 計画と呼ばれ, 宇宙科学研究所と宇宙開発事業団の共同ミッシ ヨンとして進められている。セレーネ計画の主要な目的は, 月の起源と進化の解明のためのデータを取 得すると共に，月面軟着陸等の月探查に必要な技術開発を行うことである。

セレーネは高度 $100 \mathrm{~km}$ の月の極・円軌道を周回する周回衛星, 着陸実倹機, 及びリレー衛星から構 成される。周回衛星に搭载される観測機器はリレー衛星及び着陸実験機に搭载される観測機器と連携し て月の全球钼测を行う予定である。また着陸実験機は月面に軟着陸実験を行い，軟着陸技術の習得と蓄 積が図られる予定である。本稿では，セレーネ探査機について紹介し，月挆査の意義について詳しく述 ベる。

(本文 19 ページ) 